Article

\title{
Socioeconomics Determinants to Adopt Agricultural Machinery for Sustainable Organic Farming in Pakistan: A Multinomial Probit Model
}

\author{
Muhammad Waqar Akram ${ }^{1,2, *}{ }^{\mathbb{D}}$, Nida Akram ${ }^{1}{ }^{1}$, Hongshu Wang ${ }^{1, *}$, Shahla Andleeb ${ }^{3}$, \\ Khalil Ur Rehman ${ }^{3}$, Umair Kashif ${ }^{1}$ and Syed Farhaan Hassan ${ }^{4}$ \\ 1 College of Economics \& Management, North East Forestry University, Harbin 150040, China; \\ nida.akram88@yahoo.com (N.A.); kashifumair@nefu.edu.cn (U.K.) \\ 2 Department of Business Administration, Ilma University, Main Ibrahim Hyderi Road, Korangi Creek, \\ Karachi 75190, Pakistan \\ 3 Department of Environmental Science, Government College Women University, Sialkot 51310, Pakistan; \\ shahla.andleeb@yahoo.com (S.A.); khalil.lastnamerehman@yahoo.com (K.U.R.) \\ 4 Department Business Administration, Allama Iqbal Open University, Islamabad 44000, Pakistan; \\ farhaan.powerway@gmail.com \\ * Correspondence: Waqar.akram13@yahoo.com (M.W.A.); lwanghongshu@163.com (H.W.); \\ Tel.: +86-13654555395 (M.W.A.); +86-15946002021 (H.W.)
}

Received: 6 November 2020; Accepted: 21 November 2020; Published: 24 November 2020

\begin{abstract}
Urbanization and low productivity are real threats to the sustainability of organic farming. The adoption of farm machinery plays a vital role in overcoming these threats to ensure a sustainable and more profitable organic farming model. Farm machinery can also increase farmland yield and reduce the need for labor, although the requirement of significant capital investment often prevents small farmers from buying machinery. There is an increased need to comprehend all relevant elements associated with farming machinery procurement and service delivery. In this article, we provide insight into the impact of different variables of farmers on the adoption of agricultural equipment. A total of 301 organic farmers were surveyed in three districts of Punjab, Pakistan. It was found that the most common machinery concerned herein are tube-well/pumps, tractors, tillage machinery, and thrashers/harvesters. Results from a multinomial probit estimation showed that farm machinery ownership is positively correlated with capital assets, civil infrastructure, alternative sources of power, and credit facility. The findings indicated that policymakers and stakeholders should not concentrate merely on short term planning, such as improving agricultural machinery's adoption rate. Still, they should also strive to upgrade physical infrastructure and facilities and provide credit services to create an enabling environment that can empower the citizen in adopting large scale use of agricultural machinery for long term sustainability of organic farming.
\end{abstract}

Keywords: sustainability; organic farming; farm development; farm machinery; labor; farm investment; productivity

\section{Introduction}

According to current projections, the global population is expected to reach 9.6 billion people in 2050 [1]. Consequently, the consumption of staple foods such as wheat, rice, maize, meat, and fish is predicted to proliferate, especially in the third world countries and developing nations [2]. These are the same areas where many people also live below the poverty line of USD 1.90 per day; this group of an impoverished population is predicted to increase to 274.5 million persons [3]. On the contrary, the available area of agricultural land per capita is decreasing sharply. For example, in South Asian 
countries such as Pakistan, India, Bangladesh, and Nepal, the farmland area has reduced from $0.17-0.36$ hectors per capita in 1961 to $0.12-0.24$ hectors in 2012 [4]. The rapid increase in population and the concurrent decrease in per capita farmland creates serious concern regarding whether organic agriculture can produce a higher yield and sustain the increasing demand. This problem is incredibly real for the South Asia region, which has a high population density. The pressure of food security and the low yield of organic farming may worsen the situation. Furthermore, the simultaneous expansion of other sectors and employment opportunities has resulted in rural-urban migration among the farming community. Consequently, the agriculture sector suffers from a seasonal labor force in rural areas $[5,6]$.

Recently, organic farming (OF) has been facing two main problems. Firstly, the efficiency of OF has often been undermined. Organic farming productivity is $19.3 \%$ lower than its counterpart, which translates into an increased threat to food security and organic practice sustainability [7]. The second problem is related to the shortage of rural labor. This is a pertinent issue because OF is considered an incredibly labor-intensive farming method [8]. These arguments strongly support the need to provide specific agricultural machinery for farms that fall short of their limited resource capacity. This will increase their yields and pave the way for more intensified sustainable farming practices $[9,10]$ - usually, organic farmers work on farms of smaller sizes scattered around different areas. For example, the average size of an organic farm in Pakistan is four hectares, much smaller than the Region's average farm size [11]. These small farmers will be interested in small scale machinery that can replace manual work and old traditional tools to save production costs and reduce difficult or labor-intensive work [10,12]. In addition, organic production can be a good alternative for small and medium-sized farms that have no chance of competing with large-scale and modern farms.

However, OF farmers' low purchasing power restricts them from adapting and procuring modern technologies, thus limiting the farm mechanization among Pakistani farmers [11,13]. As Ponisio et al. [7] suggested, the productivity of OF can increase by $9 \%$ through better operations and management practice. Specific farm machinery may be able to make OF more sustainable too. As agricultural yield can be improved through farm mechanization, machinery is increasingly designed and made to accommodate farmers with small and scattered lands to promote agricultural resources' sustainable use [14-16]. A good example is the utilization of strip and zero tillage, which requires investment in specialized equipment but, in return, leads to a reduction in fuel expenses, the use of water for irrigation, and time [17-19]. Despite the promised advantages, organic farmers still face problems associated with the adoption of specific machinery. These challenges must be addressed for increased mechanization of OF in Pakistan, which can be achieved via promoting the mechanization program's development.

To overcome problems associated with increased mechanization for OF, it is imperative to comprehend organic farmers' attributes regarding their adoption of or investment into agriculture machinery; in other words, whether the farmers are utilizing such small scale or essential kinds of machinery themselves, as well as renting the machinery to others. This factor is more relevant for organic farmers. Their farms' size is not as big as conventional farmers, leading to a lower preference for purchasing and owning machinery before this. However, in recent years, an increasing number of small farmers have been able to access agricultural mechanization through the enlistment of individual components [20]. Reviewing organic farmers who possess agricultural machinery can give insight into the influential factors that encourage investment in agricultural machinery. With that information, policymakers and development authorities such as commercial and agricultural bankers and administrators can allocate resources or plan investment more efficiently. Furthermore, this will create more significant insights and contribute to the scarce information surrounding farming mechanization and its associated factors. 
There are several other reasons as to why this subject is essential and worthy of research. Agriculture is one of Pakistan's most significant economic sectors, contributing one fifth or $19.3 \%$ of its GDP [21]. While recent trends showed that OF is practiced increasingly in Pakistan, it contributes to only $0.1 \%$ of the total organic agricultural output worldwide [22]. Recently, Pakistan has begun exporting organic products to the European Union. It is a lucrative business as the total market size of organic products in the European Union is 8.96 billion dollars [23]. Apart from that, China is another big potential market for Pakistani organic products through the China Pakistan Economic Corridors (CPEC) project. China's organic market size is nearly 4.19 billion dollars and multiplying [23]. To exploit such opportunities, Pakistan's OF must overcome the various challenges and improve its efficiency. The main challenges of OF included the high labor intensiveness and the shrinking rural labor forces due to rapid urbanization [5].

It must be highlighted that agricultural automation is an integral approach and advancement objective for Pakistan. Compared to other nations in the region, Pakistan's agricultural mechanization is considered under-prioritized, relying only on tractors and specific land-preparing instruments due to the sector's lack of technology [24]. Based on a 2004 survey, Pakistan had a total of 0.41 million tractors and 1.71 million farming implement or machinery, including tillage machines, cultivators, disk harrows/plows, trolleys/trailers, and tube wells/water pumps [25]. These machines' horsepower is only $0.90 \mathrm{HP}$, much lower than the international standard of 1.7HP, as described by the Food and Agriculture Organization [26]. This lack of resources leads to a lower yield and it affects the productivity of OF more severely than conventional farming as OF is a lower yield farming method to begin with [27]. Besides, Pakistan is also facing a water scarcity problem, especially considering surface water via canal irrigation in the country experienced a 19\% decline over the last year. As a result, tube-well/pump irrigation plays a critical role in Pakistan's agricultural sector [28]. Other farm machinery can also help the sustainable use of water. For instance, leveling machinery can save a significant amount of water and add USD 143.5 per hector to a farmer's gross margin. This is especially useful for countries that are heavily dependent on flood irrigation, Pakistan being one of them [29,30]. Consequently, research concerning the mechanization of Pakistan OF can provide valuable information regarding factors influencing its uptake.

Despite an extensive search, we found no large-scale studies conducted in recent years that examined organic farms' mechanization. This study aims to fill this gap in the literature. Through contextual analysis, this research will assess the organic farmers in Pakistan and classify the relevant determinants leading to the adoption of necessary and small scale machinery in OF. We will also examine factors leading to the ownership of agricultural farm machinery. In short, this study will analyze available survey data to investigate the adoption of necessary agricultural types of machinery such as tractors, harvesters/threshers, tillers (generally used for land preparation through the utilization of a tractor), and tube wells/water pumps. We will start with an analysis and discussion of the survey data, followed by an econometric model. After presenting the main findings, we will take a more in-depth look at these findings and evaluate farmers' ownership of agricultural machinery's main political implications.

\section{Materials and Methods}

\subsection{Data Description}

The data were acquired through a comprehensive survey at the districts of Toba Tek Singh, Khanewal, and Jhang in the Punjab province of Pakistan (Figure 1). These districts were selected based on the suggestion of the Lok Sanjh Foundation, the pioneer in the introduction of OF in Pakistan back in 1996. The community in these districts, such as organic farmers, villagers, and other principal stakeholders, were included in the survey. 


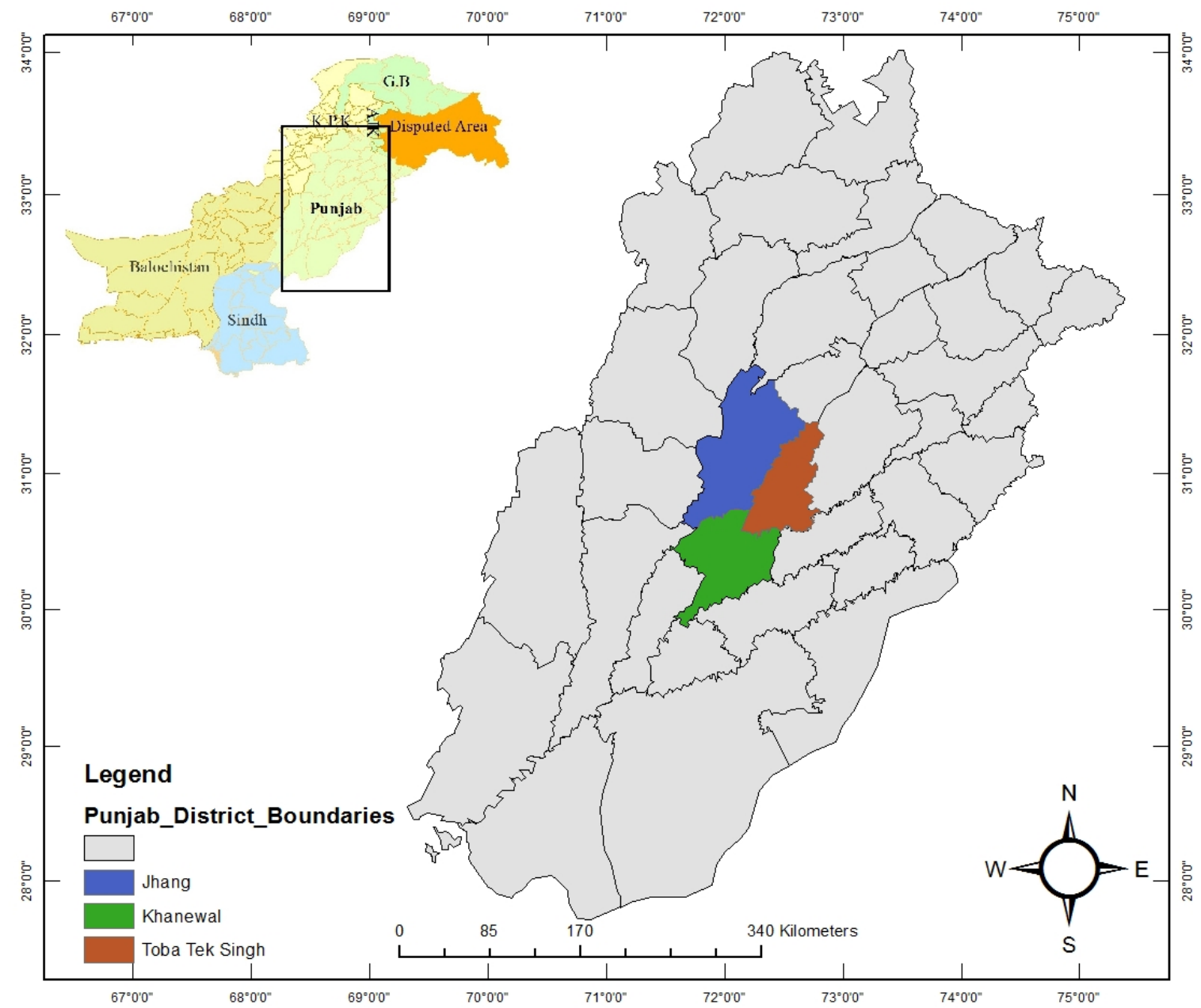

Figure 1. Survey area.

Training sessions that focused on the use of and transition to OF means and techniques were given to the farmers in the aforementioned areas through the help of the FFSs (Farmers Field Schools) and the Lok Sanjh Foundation [31]. All data concerning these farmers who were in the process of assuming OF methods were collected and analyzed to extrapolate a conclusion or result. As the environment and other cultivation conditions of other regions of Punjab Pakistan and the northern part of India are similar, the findings from this specific Region can be extended to other parts of the region.

With the help of the Lok Sanjh Foundation, we identified and selected the 400 farming households that had already adopted OF methods. The farmers were then assigned a number in alphabetical order of their names. A stratified random sampling technique was used to sample the households to ensure that all households had an equal probability of being selected regardless of the household size. This was a fundamental criterion for the identification of an organic approach and machinery use. A questionnaire was distributed to collect the data on personal characteristics, management and structure of the farms, infrastructure of the Region, opinions of the farmers, family information and characteristics, output, and input data. Overall, 400 households received a questionnaire through a cooperative effort with the Lok Sanjh Foundation. Data collection was conducted from September 2017 to February 2018. A total of 344 households returned the questionnaire, which was $89 \%$ of the total sample size of households that have adopted OF. Only 301 respondents were included in the final analysis due to missing data. 


\subsection{Model Specification and Estimation}

The following Equation (1) was developed to investigate the determinants of agricultural machinery ownership by organic farmers in Pakistan:

$$
Y_{i}=\alpha_{0}+\left(H H C_{i}\right) \varnothing+\alpha_{1}\left(\operatorname{Road}_{r a}\right)+\alpha_{2}\left(\text { Labor }_{d}\right)+\sum_{d=1}^{\partial} \beta_{j}\left(R_{j}\right)+\varepsilon_{i} .
$$

The dependent variable was expressed as $Y_{i}$; a zero-based value means that the farmer does not own any farm machinery (including tube wells, pumps, tractors, tillage equipment, thrashers, and harvesters). If a farmer owns a tube well or any other kind of water pump used for irrigation, the dummy value given would be " 1 ", " 2 " if they owned a tractor, " 3 " for tillage equipment, and " 4 " for the ownership of thrashers/harvesters. As Mottaleb et al. [32] explained in his study, this coding method was devised based on the farmer's priority and need, i.e., water is the basic necessity for agriculture, followed by a tractor as the primary source of power for tillage and harvesters. In our study area, farmers who did not have a tractor would not be able to use the other two types of machinery for tillage and harvesting purposes. The explanatory variable of household characteristics $\left(H H C_{i}\right)$ is an independent variable composed of the farmer's age, education, farm size, family members, livestock, access to credit, member of agriculture organization, other jobs, land on lease and ownership, other sources of power, and Region of the farm. Age was further categorized as young (35 years or under), middle-aged (36-56 years), and old (over 56 years). Education was also expressed according to categories, including: "illiterate," "middle school," "secondary school," and "university level." A farmer is defined as a member of any agricultural organization and has livestock assumed with a value of 1 (otherwise zero). The farmer's farmland (Ha) size would be given a dummy value of 1 if the land was leased.

Accordingly, the size of the farm per hectare in our model was determined by the area of land on lease. We also evaluated the impact of ownership types (leased or owned) on the ownership of agricultural machinery. If a household had access to credit from an institution or any personal source, the value was assumed to be 1 ; otherwise, a zero value was applied. A further dummy value of 1 was given if a household managed to use at least one agricultural machine through an energy source that did not include the machine's engine, such as renewable sources of energy or electricity; otherwise, a zero value was given. In Equation (1), $\operatorname{Road}_{r a}$ was the second independent variable that captured the effect of having road access on the farm. If a farm had a gravel or paved road, a value of 1 was given; otherwise, a zero value was assigned. Finally, the impact of the availability of working labor on mechanical adoption was evaluated via the independent variable Labor $_{d}$. This variable was obtained from an equation that captured two kinds of dummy variables. Firstly, the number of days of labor in which the family spent working on the farm and secondly, the use of hired or outsourced labor (if any). Labor accessibility can have different effects on machine ownership. For instance, if a tube well is utilized for irrigation to increase the crop growth in dry seasons, this will increase labor requirements.

Conversely, tractor, tillage, and threshers may decrease labor needs. Regional infrastructure and facilities influence the adoption of machinery. Hence, to determine whether regional factors affect farming mechanization, the independent variable $R_{j}$, which expressed the parameters of the three districts of our selected study area, was included. The scalar parameter was $a_{0}$. The vector parameters were $a, \beta$, and $\varnothing$; in which $i$ represented the household, $r a$ represented road access of the farm, $d$ represented labor days worked on the farm, and $\varepsilon$ stood for random error. 
The most widely recognized machine owned by farmers is the tube well or water pump, though it is possible for farmers to own additional farming machinery (Table 1). To explain the utilization of multiple technologies by farmers, a multinomial probit model was used. Two previous studies have adopted a similar model. Mottaleb et al. [33] applied a multinomial probit model to evaluate the determinants for hybrid rice adoption for Bangladesh, whereas Quayum et al. [34] used a single logit estimation to evaluate the adoption of power tillers.

Table 1. Farm Machinery ownership and sample of Household Farm with their Region.

\begin{tabular}{ccccc}
\hline Description & Toba Tek Singh & Jhang & Khanewal & Total \\
\hline $\begin{array}{c}\text { Household Farm } \\
\text { Numbers }\end{array}$ & 102 & 98 & 101 & 301 \\
$\begin{array}{c}\text { No Farm } \\
\text { machinery }\end{array}$ & 10 & 4 & 33 & 47 \\
$\begin{array}{c}\text { Tube-well/Water } \\
\text { Pump b }\end{array}$ & 23 & 16 & 24 & 63 \\
Tractor $^{\text {c }}$ & 10 & 23 & 12 & 45 \\
Tillage $^{\text {d }}$ & 21 & 8 & 9 & 38 \\
Thrasher $^{\text {e }}$ & 38 & 47 & 23 & 108
\end{tabular}

\footnotetext{
a Farm household has no machinery; ${ }^{\mathrm{b}}$ Farm household has Tube-well or any other kind of water pump for irrigation purposes; ${ }^{\mathrm{c}}$ Farm household has a Tractor for agriculture purposes; ${ }^{\mathrm{d}}$ Farm household has. Tillage or any other kind of implement for land preparation to cultivate the crop; ${ }^{\mathrm{e}}$ Farm household has a Thrasher or any other kind of harvester.
}

For this study, we evaluated four models to estimate the effect of these factors on the adoption of agricultural machinery by farmers and to control possible endogenous problems within the data set. First, we included all the aforementioned explanatory variables in the unlimited full model. Three other limited models (L1-L3) were also constructed whereby the nominated variables were excluded to avoid possible endogenous and redundancy issues apart from making sure that other variables of explanatory interests were isolated. For example, the size of the farm was included in the unlimited model and it can be argued that the addition of the dummy variable for owners of farmland and their related multipliers may be superfluous. Hence, in L1, we excluded the variables of farm size and land use (both owned and leased). In L2, we excluded farm size and its related multipliers and also livestock ownership. These factors were excluded because it was possible for a farmer to initially invest in mechanized farming equipment for their farm and purchase a machine before using the same machine to offer or provide services to other farmers in exchange for money. Additional investments in other resources, such as land or livestock, may also occur. Therefore, the credit facility was excluded from the L3 model because such credit could be obtained based on physical capital available through collateral means.

\section{Results}

\subsection{General Survey Results}

The characteristics of the study samples are detailed in Table 2. It shows that $78 \%, 85 \%$, and $70 \%$ of surveyed farming households in Toba Tek Singh, Jhang, and Khanewal had livestock. Our study samples comprised of $40 \%$ owned land farms and $60 \%$ leased land farms, whereby leased land farms included both rent and share-cropper arrangements. It was very surprising to find very low credit access among the households in the areas in which only $22 \%$ of households had access to credit. The infrastructure of the Region is quite good, considering that $57 \%$ of the farms included in the study had road access. Renewable energy such as alternative sources of energy which can help to reduce the cost of input was used by $35 \%$ of farmers in our sample. The usage is the lowest in Khanewal, with only $21 \%$, compared to the other two areas. 
Water is a basic need for agriculture. Due to the scarcity of surface water, many farmers either use their own tube-wells or other means to extract groundwater for irrigation. Data from our study showed that $84 \%$ of households owned a tube-well and the tractor was the primary source of power. Overall, $76 \%$ of farmers in our study owned a tractor, $60 \%$ had tillage machinery, and $48 \%$ had a thrasher/harvester (Table 2). The demographic features of households are shown in Table A1. The data showed that most household heads were of middle-age and had obtained a high school education. The average household size was found to be $6-7$ persons and most families lived in a joint family system.

Table 2. Resource endowments of household's samples by Region.

\begin{tabular}{ccccc}
\hline \multirow{2}{*}{ Description } & \multicolumn{2}{c}{ Region Wise Sample } & \\
\cline { 2 - 4 } & $\begin{array}{c}\text { Toba Tek Singh } \\
\mathbf{( \% )}\end{array}$ & $\begin{array}{c}\text { Jhang } \\
\mathbf{( \% )}\end{array}$ & $\begin{array}{c}\text { Khanewal } \\
\mathbf{( \% )}\end{array}$ & $\begin{array}{c}\text { Total Sample } \\
\mathbf{( \% )}\end{array}$ \\
\hline Households that have livestock & 78 & 85 & 70 & 78 \\
Households that have farmland ownership & 41 & 36 & 43 & 40 \\
Households with access to credit & 29 & 25 & 12 & 22 \\
Households that use an alternative source of power & 40 & 45 & 21 & 35 \\
Households farm with access to the main road & 58 & 67 & 45 & 57 \\
Households with own tube well/water pump & 90 & 96 & 67 & 84 \\
Households with own tractor & 77 & 84 & 68 & 76 \\
Households with own tillage & 67 & 60 & 53 & 60 \\
Households with own thrasher/harvester & 46 & 55 & 43 & 48 \\
\hline
\end{tabular}

\subsection{Estimation of the Unlimited Model}

All household characteristics and other possible explanatory variables were determined for the unlimited estimation model with a $1 \%, 5 \%$, and $10 \%$ significance level followed by the coefficient which explained the ownership of tube-well/pump, tractor, tillage, and thrasher (Table 3). Household characteristics such as education, membership of an agriculture organization, possession of another job outside farming, and livestock ownership were all found to have a positive correlation coefficient. Age, however, was found to have a negative correlation coefficient at $1 \%$ confidence interval. Education was revealed to have a positive relationship with tillage and thrasher ownership at the $10 \%$ significance level. This relationship was found to be non-significant when it came to tube-wells/pumps and tractors. Membership of an agricultural organization was also found to have a positive but non-significant effect on machinery ownership.

Table 3 shows the variables that had a positive correlation coefficient with the adoption of all farming machinery at a $1 \%$ level of significance, other than the possession of a job outside farming and the possession of livestock. In contrast, household members (family size) was found to have a negative correlation coefficient with the adoption of farming machinery.

The variable of farm size (ha) was found to have a positive correlation coefficient with the ownership of all types of farming machines. Overall, farm size was found to have a significant $(p<0.001)$ influence on machinery ownership, while the ownership of farmland was found to have a significant $(p<0.001)$ impact on the ownership of tillage and thrasher/harvester. Additionally, leased farmland was not found to have a significant impact on any kind of machine ownership. As for the influence of credit access, there was no correlation with machinery ownership except for tillage machinery $(p<0.10)$ (Table 4). 
The variable concerning accessibility due to infrastructure, such as road access, was revealed to have a significant relationship $(p<0.001)$ with machinery ownership. Furthermore, alternative sources of energy including renewable energy and electricity were also found to have a statistically significant positive relationship $(p<0.10)$ with farmers' adoption of machinery and the use of two kinds of machinery, specifically tillage machinery and tractors (Table 3). Our study also found that hired labor and familial members were negatively correlated with the adoption and use of all farming machinery (Table 3). Family labor days were found to have a significant negative relationship $(p<0.001)$ with machinery adoption. Labor hired or sourced from outside of the family was also found to have a statistically significant $(p<0.001)$ negative relationship with the ownership and use of a thrasher, but this relationship was not detected with other types of machines.

Table 3. Multinomial probit estimation to evaluate farm machinery ownership.

\begin{tabular}{|c|c|c|c|c|}
\hline \multirow{2}{*}{$\begin{array}{l}\text { Model Specification } \\
\text { Dependent Variable }\end{array}$} & \multicolumn{4}{|c|}{ Unlimited Model } \\
\hline & Tube-Well/Pump & Tractor & Tillage & Thrasher \\
\hline Age & $\begin{array}{c}-0.790^{* * *} \\
(-2.81)\end{array}$ & $\begin{array}{c}-0.602 * * \\
(-1.96)\end{array}$ & $\begin{array}{c}-0.826^{*} \\
(-2.57)\end{array}$ & $\begin{array}{c}-0.580 * * \\
(-2.09)\end{array}$ \\
\hline Education & $\begin{array}{l}0.201 \\
(0.80)\end{array}$ & $\begin{array}{c}0.342 \\
(1.29)\end{array}$ & $\begin{array}{c}0.470 * \\
(1.75)\end{array}$ & $\begin{array}{l}0.274 \\
(1.10)\end{array}$ \\
\hline Household Members & $\begin{array}{l}0.053 \\
(0.46)\end{array}$ & $\begin{array}{l}-0.021 \\
(-0.17)\end{array}$ & $\begin{array}{c}-0.01 \\
(-0.07)\end{array}$ & $\begin{array}{l}-0.046 \\
(-0.40)\end{array}$ \\
\hline Member of farming organization & $\begin{array}{l}-0.501 \\
(-1.17)\end{array}$ & $\begin{array}{l}0.121 \\
(0.26)\end{array}$ & $\begin{array}{l}0.184 \\
(0.38)\end{array}$ & $\begin{array}{c}0.07 \\
(0.16)\end{array}$ \\
\hline Other job apart from agriculture & $\begin{array}{c}1.227 * * * \\
(2.78)\end{array}$ & $\begin{array}{c}1.530 * * * \\
(3.20)\end{array}$ & $\begin{array}{c}1.088^{* *} \\
(2.21)\end{array}$ & $\begin{array}{c}1.098^{* *} \\
(2.50)\end{array}$ \\
\hline Livestock & $\begin{array}{c}0.911^{* *} \\
(2.10)\end{array}$ & $\begin{array}{c}1.706^{* * *} \\
(3.33)\end{array}$ & $\begin{array}{c}1.342^{* * *} \\
(2.57)\end{array}$ & $\begin{array}{c}1.42^{* * *} \\
(3.24)\end{array}$ \\
\hline Size of the farm (Hectares) & $\begin{array}{c}0.676^{* * *} \\
(4.09)\end{array}$ & $\begin{array}{c}0.714^{* * *} \\
(4.28)\end{array}$ & $\begin{array}{c}0.477^{* * *} \\
(2.77)\end{array}$ & $\begin{array}{c}0.611^{* * *} \\
(3.69)\end{array}$ \\
\hline Access to credit & $\begin{array}{l}0.718 \\
(1.12)\end{array}$ & $\begin{array}{c}1.141 \text { * } \\
(1.73)\end{array}$ & $\begin{array}{l}0.653 \\
(0.98)\end{array}$ & $\begin{array}{l}0.867 \\
(1.36)\end{array}$ \\
\hline Alternative sources like electricity & $\begin{array}{l}0.484 \\
(0.91)\end{array}$ & $\begin{array}{l}0.658 \\
(1.19)\end{array}$ & $\begin{array}{c}0.963 * \\
(1.74)\end{array}$ & $\begin{array}{c}1.110 * * \\
(2.13)\end{array}$ \\
\hline Road Access & $\begin{array}{c}0.012 * * \\
(0.03)\end{array}$ & $\begin{array}{l}1.459^{* * *} \\
(3.05)\end{array}$ & $\begin{array}{c}1.998^{* * *} \\
(3.87)\end{array}$ & $\begin{array}{c}1.265^{* * *} \\
(2.86)\end{array}$ \\
\hline Family Labor days & $\begin{array}{l}-0.873^{* *} \\
(-2.09)\end{array}$ & $\begin{array}{l}-1.049 * * \\
(-2.38)\end{array}$ & $\begin{array}{l}-1.169 \\
* * * \\
(-2.62)\end{array}$ & $\begin{array}{c}-1.267^{* * *} \\
(-3.11)\end{array}$ \\
\hline Hired Labor days & $\begin{array}{l}0.165 \\
(0.52)\end{array}$ & $\begin{array}{l}-0.501 \\
(-1.51)\end{array}$ & $\begin{array}{c}-0.11 \\
(-0.59)\end{array}$ & $\begin{array}{c}-0.763^{* * *} \\
(-2.45)\end{array}$ \\
\hline Farm land ownership & $\begin{array}{l}0.773 \\
(1.19)\end{array}$ & $\begin{array}{l}1.128 \\
(1.62)\end{array}$ & $\begin{array}{c}2.495^{* * *} \\
(3.28)\end{array}$ & $\begin{array}{c}1.676^{* * *} \\
(2.56)\end{array}$ \\
\hline Farm land on lease & $\begin{array}{l}-0.145 \\
(-0.26)\end{array}$ & $\begin{array}{c}0.49 \\
(0.82)\end{array}$ & $\begin{array}{c}1.461^{* *} \\
(2.16)\end{array}$ & $\begin{array}{l}0.646 \\
(1.17)\end{array}$ \\
\hline Region & -0.333 & -0.276 & $\underset{* *}{-0.808}$ & $-0.545^{* *}$ \\
\hline Constant & $\begin{array}{l}(-1.21) \\
-0.665 \\
(-0.38)\end{array}$ & $\begin{array}{c}(-0.91) \\
-1.649 \\
(-0.89)\end{array}$ & $\begin{array}{l}(-2.60) \\
-1.633 \\
(-0.86)\end{array}$ & $\begin{array}{c}(-1.94) \\
1.338 \\
(0.78)\end{array}$ \\
\hline Number of Households & 301 & & & \\
\hline Wald $\mathrm{Chi}^{2}(60)$ & 141.64 & & & \\
\hline Log-likelihood ratio & -313.51 & & & \\
\hline Prob $>\mathrm{Chi}^{2}$ & 0.00 & & & \\
\hline
\end{tabular}

Robust standard errors are in parentheses ${ }^{*}, * *, * *$ shows the level of significance at $10 \%, 5 \%$, and $1 \%$, respectively. 
Table 4. Multinomial Probit estimation to evaluate farm Machinery ownership.

\begin{tabular}{|c|c|c|c|c|c|c|c|c|c|c|c|c|}
\hline \multirow{2}{*}{$\begin{array}{c}\text { Model } \\
\text { Specification } \\
\begin{array}{c}\text { Dependent } \\
\text { Variable }\end{array}\end{array}$} & \multicolumn{4}{|c|}{ Limited Model L-1 } & \multicolumn{4}{|c|}{ Limited Model L-2 } & \multicolumn{4}{|c|}{ Limited Model L-3 } \\
\hline & Tube-Well/Water-Pump & Tractor & Tillage & Thrasher & Tube-Well/Water-Pump & Tractor & Tillage & Thrasher & Tube-Well/Water-Pump & Tractor & Tillage & Thrasher \\
\hline Age & $\begin{array}{c}-0.884 * * * \\
(-3.78)\end{array}$ & $\begin{array}{c}-0.715 * * * \\
(-2.79)\end{array}$ & $\begin{array}{c}-0.853 * * * \\
(-3.19)\end{array}$ & $\begin{array}{c}-0.693 * * * * \\
(-2.99)\end{array}$ & $\begin{array}{c}-0.953 * * * \\
(-4.12)\end{array}$ & $\begin{array}{c}-0.828 * * * \\
(-3.28)\end{array}$ & $\begin{array}{l}-0.974 * * * * \\
(-3.59)\end{array}$ & $\begin{array}{c}-0.803 * * * \\
(-3.54)\end{array}$ & $\begin{array}{c}-1.021 * * * \\
(-4.63)\end{array}$ & $\begin{array}{c}-0.932 * * * \\
(-3.90)\end{array}$ & $\begin{array}{c}-1.039 * * * \\
(3.99)\end{array}$ & $\begin{array}{c}-0.860^{* * * *} \\
(-3.98)\end{array}$ \\
\hline Education & $\begin{array}{l}0.200 \\
(0.96)\end{array}$ & $\begin{array}{c}0.432^{* *} \\
(1.95)\end{array}$ & $\begin{array}{c}0.506^{* *} \\
(2.27)\end{array}$ & $\begin{array}{l}0.316 \\
(1.52)\end{array}$ & $\begin{array}{l}0.267 \\
(1.27)\end{array}$ & $\begin{array}{c}0.387^{*} \\
(1.75)\end{array}$ & $\begin{array}{c}0.420^{* *} \\
(1.85)\end{array}$ & $\begin{array}{l}0.282 \\
(1.35)\end{array}$ & $\begin{array}{l}0.262 \\
(1.32)\end{array}$ & $\begin{array}{c}0.394^{*} \\
(1.87)\end{array}$ & $\begin{array}{c}0.419 * * \\
(1.93)\end{array}$ & $\begin{array}{l}0.280 \\
(1.41)\end{array}$ \\
\hline Household & -0.001 & -0.089 & -0.045 & -0.101 & 0.088 & 0.003 & 0.045 & -0.015 & 0.072 & -0.026 & 0.027 & -0.026 \\
\hline & $(-0.01)$ & $(-0.90)$ & $(-0.44)$ & $(-1.08)$ & $(0.99)$ & $(0.11)$ & $(0.45)$ & $(-0.17)$ & $(0.84)$ & $(-0.29)$ & $(0.28)$ & $(-0.31)$ \\
\hline $\begin{array}{c}\text { Member of farming } \\
\text { organization }\end{array}$ & 0.177 & $0.953^{* * *}$ & $0.934 * *$ & $0.816^{* *}$ & 0.257 & $0.829^{* *}$ & $0.767 *$ & $0.723 * *$ & 0.245 & $0.794^{* *}$ & $0.729^{* *}$ & $0.702 * *$ \\
\hline & $(0.53)$ & $(2.55)$ & $(2.40)$ & $(2.39)$ & $(0.77)$ & $(2.26)$ & (1.95) & $(2.17)$ & $(0.76)$ & $(2.24)$ & $(1.91)$ & (2.18) \\
\hline $\begin{array}{l}\text { Other job apart } \\
\text { from agriculture }\end{array}$ & 0.668 * & $0.980^{* * *}$ & $0.818^{* *}$ & 0.603 * & $0.791 * *$ & $1.036 * * *$ & $0.830 * *$ & $0.648 * *$ & - & - & - & - \\
\hline & $(1.94)$ & $(2.60)$ & $(2.11)$ & $(1.74)$ & $(2.33)$ & $(2.79)$ & (1.79) & (1.92) & & & & \\
\hline livestock & $\begin{array}{c}0.799 * * \\
(2.22)\end{array}$ & $\begin{array}{c}1.584^{* * *} \\
(3.67)\end{array}$ & $\begin{array}{c}1.393^{* * * *} \\
(3.16)\end{array}$ & $\begin{array}{c}1.391 * * * \\
(3.75)\end{array}$ & - & - & - & - & - & - & - & - \\
\hline $\begin{array}{l}\text { Size of the farm } \\
\text { (Hectares) }\end{array}$ & - & - & - & - & - & - & - & - & - & - & - & - \\
\hline Access to credit & $\begin{array}{c}0.952 * \\
(1.86)\end{array}$ & $\begin{array}{c}1.172 * * \\
(2.18)\end{array}$ & $\begin{array}{c}0.933 * \\
(1.71)\end{array}$ & $\begin{array}{c}1.084 * * \\
(2.10)\end{array}$ & $\begin{array}{c}0.942 * \\
(1.86)\end{array}$ & $\begin{array}{c}1.204 * * \\
(2.28)\end{array}$ & $\begin{array}{c}0.973 * \\
(1.79)\end{array}$ & $\begin{array}{c}1.097^{* *} \\
(2.16)\end{array}$ & - & - & - & - \\
\hline $\begin{array}{l}\text { Alternative sources } \\
\text { like electricity }\end{array}$ & 0.785 * & $1.049^{* *}$ & $1.185^{* * *}$ & $1.349^{* * *}$ & $0.862 * *$ & $1.113^{* *}$ & $1.25 * * *$ & $1.418^{* * *}$ & $0.884 * *$ & $1.154^{* * *}$ & $1.264^{* * *}$ & $1.425^{* * *}$ \\
\hline & (1.85) & $(2.36)$ & $(2.65)$ & $(3.21)$ & $(2.02)$ & $(2.51)$ & $(2.76)$ & (3.38) & (2.15) & $(2.24)$ & $(2.89)$ & $(3.54)$ \\
\hline Road Access & - & - & - & - & $\begin{array}{l}-0.317 \\
(-0.90)\end{array}$ & $\begin{array}{c}1.007^{* * * *} \\
(2.75)\end{array}$ & $\begin{array}{c}1.510^{* * * *} \\
(3.65)\end{array}$ & $\begin{array}{c}0.862 * * * \\
(2.56)\end{array}$ & $\begin{array}{l}-0.293 \\
(-0.87)\end{array}$ & $\begin{array}{c}0.998 * * * * \\
(2.83)\end{array}$ & $\begin{array}{c}1.517 * * * \\
(3.76)\end{array}$ & $\begin{array}{c}0.863 * * * * \\
(2.65)\end{array}$ \\
\hline Family Labor days & $\begin{array}{r}-0.493 \\
(-1.51)\end{array}$ & $\begin{array}{c}-0.754 * * \\
(-2.18)\end{array}$ & $\begin{array}{c}-0.739 * * \\
(-2.10)\end{array}$ & $\begin{array}{c}-0.848 * * * \\
(-2.66)\end{array}$ & $\begin{array}{l}-0.481 \\
(-1.49)\end{array}$ & $\begin{array}{c}-0.723 * * \\
(-2.11)\end{array}$ & $\begin{array}{c}-0.627 * \\
(-1.75)\end{array}$ & $\begin{array}{c}-0.804 * * * \\
(-2.57)\end{array}$ & $\begin{array}{l}-0.367 \\
(-1.20)\end{array}$ & $\begin{array}{c}-0.585 * \\
(-1.82)\end{array}$ & $\begin{array}{l}-0.508 \\
(-1.48)\end{array}$ & $\begin{array}{c}-0.696^{* *} \\
(-2.35)\end{array}$ \\
\hline Hired Labor days & $\begin{array}{l}-0.057 \\
(-0.23)\end{array}$ & $\begin{array}{c}-0.553 * * \\
(-2.12)\end{array}$ & $\begin{array}{l}-0.373 \\
(-1.37)\end{array}$ & $\begin{array}{c}-0.856 * * * \\
(-3.51)\end{array}$ & $\begin{array}{l}0.094 \\
(0.37)\end{array}$ & $\begin{array}{c}-0.432^{*} \\
(-1.66)\end{array}$ & $\begin{array}{l}-0.210 \\
(-0.76)\end{array}$ & $\begin{array}{c}-0.727 * * * * \\
(-2.99)\end{array}$ & $\begin{array}{l}0.126 \\
(0.53)\end{array}$ & $\begin{array}{l}-0.386 \\
(-1.57)\end{array}$ & $\begin{array}{l}-0.152 \\
(-0.59)\end{array}$ & $\begin{array}{c}-0.654 * * * * \\
(-2.86)\end{array}$ \\
\hline $\begin{array}{l}\text { Farm land } \\
\text { ownership }\end{array}$ & - & - & - & - & - & - & - & - & - & - & - & - \\
\hline Farm land on lease & - & - & - & - & - & - & - & - & - & - & - & - \\
\hline Region & $\begin{array}{l}-0.350 * \\
(-1.71)\end{array}$ & $\begin{array}{l}-0.185 \\
(-0.81)\end{array}$ & $\begin{array}{l}-0.598 * * * \\
(-2.59)\end{array}$ & $\begin{array}{c}-0.436 * * \\
(-2.09)\end{array}$ & $\begin{array}{c}-0.393 * * \\
(-1.95)\end{array}$ & $\begin{array}{l}-0.222 \\
(-0.99)\end{array}$ & $\begin{array}{l}-0.671 * * * \\
(-2.85)\end{array}$ & $\begin{array}{l}-0.492 * * * \\
(-2.41)\end{array}$ & $\begin{array}{c}-0.543 * * * \\
(-2.82)\end{array}$ & $\begin{array}{c}-0.426 * * \\
(-2.02)\end{array}$ & $\begin{array}{c}-0.831 * * * \\
(-3.72)\end{array}$ & $\begin{array}{c}-0.645^{* * * *} \\
(-3.34)\end{array}$ \\
\hline Constant & $\begin{array}{c}1.66 \\
(1.25)\end{array}$ & $\begin{array}{l}1.808 \\
(1.26)\end{array}$ & $\begin{array}{l}1.668 \\
(1.13)\end{array}$ & $\begin{array}{c}4.257^{* * * *} \\
(3.20)\end{array}$ & $\begin{array}{l}1.504 \\
(1.15)\end{array}$ & $\begin{array}{l}1.768 \\
(1.27)\end{array}$ & $\begin{array}{l}1.008 \\
(0.68)\end{array}$ & $\begin{array}{c}4.121^{* * * *} \\
(3.20)\end{array}$ & $\begin{array}{c}2.016^{*} \\
(1.79)\end{array}$ & $\begin{array}{c}2.780^{* *} \\
(2.18)\end{array}$ & $\begin{array}{l}1.675 \\
(1.23)\end{array}$ & $\begin{array}{c}4.594 * * * \\
(3.84)\end{array}$ \\
\hline $\begin{array}{l}\text { Number of } \\
\text { Household }\end{array}$ & 301 & & & & 301 & & & & 301 & & & \\
\hline Wald $\mathrm{Chi}^{2}(60)$ & 110.64 & & & & 126.64 & & & & 123.77 & & & \\
\hline $\begin{array}{l}\text { Log pseudo } \\
\text { likelihood ratio }\end{array}$ & -369.43 & & & & -358.89 & & & & -367.04 & & & \\
\hline 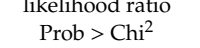 & 0.000 & & & & 0.000 & & & & 0.000 & & & \\
\hline $\begin{array}{l}\text { Log Likelihood } \\
\text { Ratio Chi2 (16) }\end{array}$ & $111.83^{a}$ & & & & $90.77^{\mathrm{b}}$ & & & & $107.06^{\mathrm{c}}$ & & & \\
\hline Probability > Chi2 & 0.000 & & & & 0.000 & & & & 0.000 & & & \\
\hline
\end{tabular}

The robust standard error is in parentheses *,***** shows the level of significance at 10\%, 5\%, and 1\%, respectively; Likelihood ratio with the assumptions $\left({ }^{a}\right)$ Limited model (L-1) nested in the unlimited model; $\left(^{(}\right)$Likelihood ratio with the assumption of the Limited model (L-2) nested in the unlimited model; $\left(^{c}\right)$ Likelihood ratio with the assumption of the Limited model (L-3) nested in the unlimited model. 


\subsection{Estimation of the Limited Model}

The first limited model, L-1, excluded the explanatory variables such as road access, size of the farm, and land ownership (owned and leased by the farmer). In the second limited model, L-2 excluded livestock, farm size, and related variables seen in the first model. In the third limited model, L-3 excluded farm size and associated variables, external sources of funding variables (such as access to credit), and the non-farming job variable. The variables relevant to financing (credit access and possession of job outside of agriculture), alternative sources of power (renewable energy and electricity), and infrastructure (road access) were all found to be statistically significant at a $0.01,0.05$, and 0.1 level within the first (L-1) and second (L-2) limited models (Table 4).

Therefore, the estimation functions in the L-1 and L-2 models showed that external financing, road access, and alternative power sources have a strong relationship with the adoption of farm machinery, specifically with the ownership of a tractor, tillage machinery, and a thrasher. The findings of the L-2 model supported the argument that credit access and road access do not play a significant role in the ownership of farm machinery. The ownership of farm machinery still depends mainly on farm size and land usage rights.

In the third limited model (L-3), in addition to excluding any possible outstanding endogenous factors, we also excluded other jobs, credit access, ownership of livestock, and the size of the farm and associated variables. Similar to the predicted function in the L-1, L-2, and L-3 models, after statistical regression analysis, the effect of power from alternative sources and road access to the farm on the ownership of farm machinery was found to be statistically significant $(p<0.001)$. The personal attributes such as age, education level, and membership of agriculture organization were also significant in all three limited models (L-1 to L-3), so there was no endogeneity problem. We have proved that the regional variable had a significant $(p<0.001)$ impact on machinery adoption based on the unlimited model (Table 3) and all three of the limited models (Table 4). This means that the infrastructure and the flow of information are critical in farm mechanization.

To verify the predicted model, we performed a post estimation's log-likelihood ratio test by placing all limited models (L-1, L-2, and L-3) within an unlimited model. The likelihood ratio (LR) was 111.83 for the limited models L-1, 90.77 for L-2, and 107.06 for L3. All three ratios were found to be statistically significant at a $1 \%$ level. Table 4 shows that the unlimited model estimation is more satisfactory when estimating machinery ownership and adoption.

\section{Discussion}

Farmers with insufficient capital can be facilitated by arranging agricultural equipment and machinery on rent to promote sustainable agriculture. The availability of various machinery and technical support from agrarian professionals is the main concern for achieving and expanding organic agricultural trends in countries with a poor economic background but rich agricultural potential, like in South Asia. Literature is scarce on this issue and only a few published studies have investigated these questions. Previous empirical studies in the field examined this issue in the general context of the whole agriculture sector but have not emphasized OF specifically.

Moreover, literature also lacked other significant parameters like domestic characteristics, socioeconomic conditions, and infrastructure status related to agricultural machinery ownership. Anyhow, this study included a series of variants observed previously. Considering the brief temporal developments of the appropriate policies in Pakistan's agricultural fields, the conversion of the agricultural sector from a traditional setup to mechanization has always remained a priority. This is why the findings of the present study will be a big step towards bridging the documentation and knowledge gaps in this area. Our research highlights the most critical factors affecting organic farm ownership of necessary agricultural machinery in Pakistan, including well pumps/tubes, tractors, plowing, and harvesting machines.

This study's overall results showed that it is difficult for organic farmers to obtain financial support through proper channels. This is because of a shortness in Government funding for organic 
farmers. Most of the farmers are dependent on private capital and resources to finance their agricultural activities. Kaleem et al. [35] stated that most farmers obtain loans from intermediaries or agents and are thus compelled to sell their products to the same vendors or middlemen at cheaper rates than market rates. Literature also represented that only $10 \%$ of all financial deals are done in cash due to the complex documentation system of public banks and institutions; furthermore, they are charging higher transfer rates.

Many studies highlighted the issues of road infrastructure with agricultural development to access various necessary resources for the agricultural sector like energy and other relevant applications (mainly for tube-well/irrigation pumps), which has a close association with the ownership of all types of agricultural machinery at the domestic level. However, the connection between road access and ownership of the irrigation pump is insignificant. This may be observed due to fixed attributes of the irrigation pump/tube-well. On the contrary, the road network is believed to be an essential factor in tractor ownership. The roads allow farmers to transport their crops to the market and increase income-generating procedures. Besides, specific carpet roads or expressways must transport agricultural machinery such as threshers/harvesters from one city to another.

Furthermore, the transport infrastructure in the present study area is pretty good because the designated area is in the middle of Punjab. This region connects the southern provinces of Punjab and Sindh to the country's main powers; here, agricultural infrastructure and access to roads is significantly better. Besides, a project started by China, the Pakistan Economic Corridor (CPEC), has also helped to improve infrastructure across the country by developing road and communication construction projects [36]. There has not been much usage of substitute energy sources, such as energy resources from natural/renewable resources, in this region. The OF industry remains highly dependent on oil use, which increases input costs and affects the financial status of organic farming development. Moreover, in Pakistan, electricity consumption in the agricultural sector is also much lower than in other developed countries because of poor maintenance in the energy and power sectors to fulfill the requirement sustainably.

Water resources are an essential requirement for the agricultural sector. Pakistan relies heavily on the Indus Watershed Irrigation System (IBIS), which was formulated and designed almost a hundred years ago to increase water availability for community settlements and the farming industry [37]. Over the past few decades, water availability from IBIS has decreased rapidly. Studies concluded that only $10 \%$ of total agricultural water is required in Pakistan from underground water resources, but that is not true for the Punjab Province, where almost $90 \%$ of all farming land is watered with underground water by using pumping tube wells [38]. These results are consistent with our research, with most farmers relying on groundwater for irrigation and having tube wells to meet their water needs.

Among various tools of agricultural mechanization, tractors play a vital role in the agriculture sector of Pakistan. Tractors are the primary source of power for many farmers, representing the first step toward farming mechanization. It also helps the farmers use different types of agriculture tools like tillage, harvesters, or trolleys. In this study, we found that tractors are the priority for farmers in the study area. Other types of machinery are linked with design and the specific requirement with reference to farmers (Table 2).

The unlimited model results show that the household's specific characteristics play a more significant role in the application of agricultural machinery, especially the age of the farmer. Old age farmers are less likely to use the machines. The same findings were reported in the study conducted about OF by Ullah et al. [39]. Middle-aged farmers are more interested in implementing OF than older farmers in Pakistan. Membership of agricultural organizations has a positive effect on machine ownership. A large number of families in our study were members of agricultural organizations, possibly due to a large number of NGOs working to promote OF in cooperation with the Lok Sanjh Foundation.

Moreover, our research finds that farmers running small businesses or doing some other jobs and agricultural farming can generate more financial resources than farmers only linked with agricultural 
farming. Likewise, if the farmer's household size is small, the family workforce may not be enough to manage the farm optimally. Therefore, this can motivate farmers to convert traditional farming into mechanized farming. The results of this study on family specifications and applications of agricultural machinery support this argument. This finding is also consistent with small-scale machine adaptation in Bangladesh [32] and the implementation of contemporary techniques in rice cultivation in the Philippines [40].

The farmers' economic condition and farming size have a positive and vital relationship with their modern agricultural equipment possession. Research shows that agriculturalists with more arable land and livestock are more likely to own their own farm machinery. This is not surprising because robust control of underlying assets will best reflect the total means accessible to farmers. Furthermore, the result is much more fascinating. The farmers who own the land are more likely to hold agricultural machinery than those who rent it. Besides, larger farms seem to have more support for machinery; this is why policymakers and stakeholders need to emphasize expanding the use of appropriate mechanisms to broaden the access of small landholders and private investors and people looking to invest in agriculture on a small scale. Such projects aim to foster the advancement and development of the business model to lead the private sector by encouraging the purchase of agricultural machinery via home-grown markets. One example is the M4P or core value chain project, which is about "creating markets for the poor" [41]. The results of this study highlighted that farmers with small scale agricultural land ownership, even though they rent a large area of land for farming, are less interested in investing in agricultural machinery. Still, this does not hinder their ability or rights to use the tools. OF development plans should enhance the administrative arrangements and allocation procedures to ensure agricultural machinery's availability at an affordable price for farmers with smaller agricultural landholders.

Another important finding from this study is an insignificant relationship between credit access of the farmers for buying machinery and machine ownership. The farmers prefer to take loans from local agents/middlemen to sell their commodities to that specific agent at lower rates. A significant factor of this situation is the tough documentation process of the Bank to release money. Another possible explanation for this is the religion of the study population. Most Pakistani farmers are Muslims, so they tend to steer towards traditional banking systems to avoid usury. As stated in the Holy Qur'an, Surat Al-Omran, Verse 130: "O you who believe, indulge in double and double indifference, and fear God, in the hope that you will be blessed with good." The local agent/middleman model often causes financial crises to farmers. So, they avoid purchasing machinery with a credit facility. Furthermore, the study mentioned the importance of easy access to roads. Aside from better corporal connectivity, access to roads also improves the flow of information to farmers and agricultural workers [42].

In organic farming, mainly tractors and irrigation pumps utilize diesel for running engines in the case of energy consumption. OF is very sensitive to water and its availability. Due to severe electricity shortages, sudden and unexpected power cuts, and large initial investments in installing renewables, most farmers still wanted to depend on diesel engines. However, the present study highlighted that other energy sources' influence on farmers' adoption of agricultural tools and equipment could not be ignored. It can be concluded that saving operating costs by using renewable energy resources could motivate advanced farmers to own agricultural machinery. It is also discussed in scientific literature [43] that electricity or renewable energy sources have lower operating costs than current energy sources.

Due to the rapid decline in the countryside workforce, agriculturists are also in a difficult situation if they were to choose agricultural machinery instead of labor. Current results show that farmer families with more family members who wish to work in the fields are less likely to purchase and own farm machinery. A farmer who can employ low-cost family labor without having to outsource may incur additional costs. Therefore, some farmers do not feel the need to invest in agricultural machinery. On the contrary, if the farmer does not receive help from his family and needs to hire outside help from people outside the home, he will feel more entitled to use the available capital for investment and machines to save time and money [32]. 


\section{Conclusions}

Mechanization in organic farming can play an essential role in promoting and maintaining practices widely known as labor-intensive agricultural technologies. A comprehensive view of the economic and social variables affecting farmers' purchasing and use of agricultural machinery for sustainable OFs will be invaluable for decisionmakers to make useful policies and will help budget distribution, as well as resource planning and management. The infrastructure improvements necessary in rural areas of Pakistan are basics to enhancing the possession of farm machines and equipment. One way is to rent agricultural machinery to small, organic farmers. Easy access to credit as an essential share of mechanization efforts can enable sustainable development and reduce production risks for farmers. In short, policymakers/decisionmakers and developers wishing to improve farmers' farming mechanization in the country are required to consider increasing their needs and conditions as needed. Besides, it is desirable to use small scale and cost-effective agricultural machinery in stages, facilitating organic agricultural mechanization and increasing the total production of organic productivity.

Author Contributions: M.W.A. and H.W. conceptualized the study design idea, performed the statistical analysis, and wrote the manuscript. N.A., S.F.H., U.K., S.A., and K.U.R. helped in the data collection and provided their intellectual insights. All authors have read and agreed to the published version of the manuscript.

Funding: This research funded by Northeast Forestry University Harbin.

Acknowledgments: We would like to acknowledge the Lok Sanjh Foundation Pakistan for providing technical data related to this study.

Conflicts of Interest: The authors of this research declare no conflict of interest.

\section{Appendix A}

Table A1. Descriptive Statistics.

\begin{tabular}{|c|c|c|c|}
\hline Variables & Description & Mean & Std. Deviation \\
\hline Age & $\begin{array}{l}1=\text { Young, up to } 35 \text { years; } 2=\text { Middle age, } \\
\text { " } 36 \text { To } 55 \text { " Years; } 3=\text { Old, more than } 55 \text { years }\end{array}$ & 1.88 & 0.72 \\
\hline Education & $\begin{array}{c}0=\text { Illiterate, } 2=\text { Middle school, } 3=\text { middle to } \\
\text { secondary school, } 4=\text { University degree }\end{array}$ & 1.52 & 0.86 \\
\hline Household & Number of household members & 6.88 & 1.84 \\
\hline $\begin{array}{c}\text { Member of farming } \\
\text { organization }\end{array}$ & $\begin{array}{l}\text { Member of any agriculture organization } \\
\qquad 0=\text { No, } 1=\text { yes }\end{array}$ & 0.66 & 0.48 \\
\hline $\begin{array}{l}\text { Another job apart } \\
\text { from agriculture }\end{array}$ & $\begin{array}{l}\text { Household head has another job with } \\
\text { agriculture farming } 0=\text { No, } 1=\text { Yes }\end{array}$ & 0.60 & 0.49 \\
\hline Livestock & Household have livestock $0=$ No, $1=$ Yes & 0.77 & 0.42 \\
\hline Size of the farm (hectares) & Size of agriculture farm in hectares & 4.50 & 3.72 \\
\hline Access to credit & $\begin{array}{l}\text { Household have access to Institutions or } \\
\text { personal sources of credit; } 0=\text { No, } 1=\text { Yes }\end{array}$ & 0.22 & 0.41 \\
\hline $\begin{array}{l}\text { Alternative sources } \\
\text { like electricity }\end{array}$ & $\begin{array}{l}\text { Household have alternative source of power; } \\
\qquad 0=\mathrm{No}, 1=\text { Yes }\end{array}$ & 0.35 & 0.48 \\
\hline Road Access & Farm situated on main road; $0=$ No, $1=$ Yes & 0.57 & 0.50 \\
\hline Family Labor days & $\begin{array}{l}\text { Family members spend days for labor work on } \\
\text { farm; } 0=1 \text { to } 10 \text { days, } 1=11 \text { To } 15 \text { days, } 2=16 \\
\text { to } 20 \text { days, } 3=\text { More than } 20 \text { days }\end{array}$ & 1.51 & 0.53 \\
\hline Hired Labor days & $\begin{array}{c}\text { Hire labor spend days for labor work on farm; } \\
0=1 \text { to } 10 \text { days, } 1=11 \text { to } 15 \text { days, } 2=16 \text { to } 20 \\
\text { days, } 3=\text { More than } 20 \text { days }\end{array}$ & 2.72 & 0.73 \\
\hline Farm land ownership & $\begin{array}{l}\text { Household owned the farmland; } \\
\qquad 0=\text { No, } 1=\text { Yes }\end{array}$ & 0.40 & 0.49 \\
\hline Farm land on lease & $\begin{array}{l}\text { Household cultivate land under lease contract; } \\
\qquad 0=\text { No, } 1=\text { Yes }\end{array}$ & 0.41 & 0.49 \\
\hline $\begin{array}{l}\text { Household has a water } \\
\text { pump/tube well }\end{array}$ & $\begin{array}{l}\text { Household have a Tubewell/waterpump; } 0= \\
\text { No, } 1=\text { Yes }\end{array}$ & 0.84 & 0.36 \\
\hline Household has a tractor & Household own a tractor; $0=$ No, $1=$ Yes & 0.76 & 0.43 \\
\hline Household has a tillage & Household own a Tillage; $0=$ No, $1=$ Yes & 0.60 & 0.49 \\
\hline $\begin{array}{l}\text { Household has a } \\
\text { thrasher/harvester }\end{array}$ & $\begin{array}{l}\text { Household own a Thrasher/Harvester; } \\
\qquad 0=\text { No, } 1=\text { Yes }\end{array}$ & 0.48 & 0.50 \\
\hline
\end{tabular}




\section{References}

1. Gerland, P.; Raftery, A.E.; Ševčíková, H.; Li, N.; Gu, D.; Spoorenberg, T.; Alkema, L.; Fosdick, B.K.; Chunn, J.; Lalic, N. World population stabilization unlikely this century. Science 2014, 346, 234-237. [CrossRef]

2. Godfray, H.C.J.; Garnett, T. Food security and sustainable intensification. Phil. Trans. R. Soc. B 2014, 369, 20120273. [CrossRef] [PubMed]

3. WorldBank. The World Bank Poverty and Equity. Available online: http://databank.worldbank.org/data/ reports.aspx?source=poverty-and-equity-database (accessed on 23 October 2018).

4. WorldBank. World Development Indicators 2018: Employment in agriculture (\% of total employment). Available online: http://databank.worldbank.org/data/reports.aspx?Code=PAK\&id=556d8fa6\&report_ name=Popular_countries\&populartype=country\&ispopular=y\# (accessed on 23 October 2018).

5. Zhang, X.; Rashid, S.; Ahmad, K.; Ahmed, A. Escalation of real wages in Bangladesh: Is it the beginning of structural transformation? World. Dev. 2014, 64, 273-285. [CrossRef]

6. Akram, N.; Akram, M.W.; Wang, H.; Mehmood, A. Does land tenure systems affect sustainable agricultural development? Sustainability 2019, 11, 3925. [CrossRef]

7. Ponisio, L.C.; M'Gonigle, L.K.; Mace, K.C.; Palomino, J.; de Valpine, P.; Kremen, C. Diversification practices reduce organic to conventional yield gap. Proc. R. Soc. B 2015, 282, 20141396. [CrossRef] [PubMed]

8. Demiryurek, K.; Ceyhan, V. Economics of organic and conventional hazelnut production in the Terme district of Samsun, Turkey. Renew. Agric. Food. Syst. 2008, 23, 217-227. [CrossRef]

9. FAO (Food and Agriculture Organization of the United Nations). Agricultural Mechanization in Africa, Time for Action. Planning Investment for Enhanced Agricultural Productivity Report of an Expert Group Meeting. Vienna and Rome, Food and Agriculture Organization of the United Nations and (UNFAO) United Nations Industrial Development Organization (UNIDO). 2008. Available online: http: //www.fao.org/docrep/017/k2584e/k2584e.pdf (accessed on 23 November 2020).

10. Kienzle, J.; Ashburner, J.E.; Sims, B.G. Mechanization for Rural Development; FAO: Rome, Italy, 2013.

11. Akram, M.W.; Akram, N.; Hongshu, W.; Mehmood, A. An assessment of economic viability of organic farming in Pakistan. Custos e Agronegocio Online 2019, 15, 141-169.

12. WorldBank. Agriculture for Development, World Development Report 2008; The International Bank for Reconstruction and Development/The World Bank: Washington, DC, USA, 2014.

13. Ur Rehman, T.; Khan, M.U.; Tayyab, M.; Akram, M.W.; Faheem, M. Current status and overview of farm mechanization in Pakistan-A review. Agric. Eng. Int. 2016, 18, 83-93.

14. Krupnik, T.J.; Valle, S.S.; Islam, S.; Hossain, A.; Gathala, M.K.; Qureshi, A.S. Energetic, hydraulic and economic efficiency of axial flow and centrifugal pumps for surface water irrigation in Bangladesh. Irrig. Drain. 2015, 64, 683-693. [CrossRef]

15. Krupnik, T.J.; Santos Valle, S.; McDonald, A.; Justice, S.; Hossain, I.; Gathala, M. Made in Bangladesh: Scale-Appropriate Machinery for Agricultural Resource Conservation; CIMMYT: Mexico City, Mexico, 2013.

16. Baudron, F.; Sims, B.; Justice, S.; Kahan, D.G.; Rose, R.; Mkomwa, S.; Kaumbutho, P.; Sariah, J.; Nazare, R.; Moges, G. Re-examining appropriate mechanization in Eastern and Southern Africa: Two-wheel tractors, conservation agriculture, and private sector involvement. Food Secur. 2015, 7, 889-904. [CrossRef]

17. Erenstein, O.; Laxmi, V. Zero tillage impacts in India's rice-wheat systems: A review. Soil Tillage Res. 2008, 100, 1-14. [CrossRef]

18. Fileccia, T. Importance of Zero-Tillage with High Stubble to Trap Snow and Increase Wheat Yields in Northern Kazakhstan; Food and Agriculture Organization of the United Nations (FAO), Investment Centre Division: Rome, Italy, 2009; Available online: ftp://ftp.fao.org/docrep/fao/012/ak166e/ak166e00.pdf (accessed on 14 May 2015).

19. Krupnik, T.; Yasmin, S.; Shahjahan, M.; McDonald, A.; Hossain, K.; Baksh, E.; Hossain, F.; Kurishi, A.; Miah, A.; Mamun, M.A. Productivity and farmers' perceptions of rice-maize system performance under conservation agriculture, mixed and full tillage, and farmers' practices in rainfed and water-limited environments of southern Bangladesh. In Proceedings of the 6th World Congress on Conservation Agriculture, Winnipeg, MB, Canada, 22-25 June 2014.

20. Biggs, S.; Justice, S. Rural and Agricultural Mechanization: A History of the Spread of Small Engines in Selected Asian Countries. 2015. Available online: https://papers.ssrn.com/sol3/papers.cfm?abstract_id=2623612 (accessed on 23 November 2020). 
21. MOF. Pakistan Economic Survey 2016-2017; Government of Pakistan, Finance Division, Economic Affairs Wing: Islambad, Pakistan, 2016-2017.

22. IFOAM. The World of Organic Agriculture, Statistics E Emerging Trend 2018; IFOAM: Bonn, Germany, 2018.

23. Willer, H.; Lernoud, J. The World of Organic Agriculture. Statistics and Emerging Trends 2018; 303736307X; Research Institute of Organic Agriculture FiBL and IFOAM Organics International: Nuremberg, Germany, 2019.

24. FAO. Food and Agriculture Organization Statistical Year Book 2014; Regional Office for Asia and the Pacific: Bangkok, Thailand, 2014.

25. GOP. Pakistan Agricultural Machinery Census 2004; Agriculture Census Organization, Pakistan Bureau of Statistics, Eds.; Government of Pakistan: Islambad, Pakistan, 2004.

26. MOF. Pakistan Economic Survey 2010-2011; MOF, Ed.; Government of Pakistan, Finance Division, Economic Affairs Wing: Islambad, Pakistan, 2010-2011.

27. Reganold, J.P.; Wachter, J.M. Organic agriculture in the twenty-first century. Nat. Plants 2016, $2,15221$. [CrossRef] [PubMed]

28. MOF. Pakistan Economic Survey 2018-2019; MOF, Ed.; Government of Pakistan, Finance Division, Economic Affairs Wing: Islambad, Pakistan, 2018-2019.

29. Aryal, J.P.; Mehrotra, M.B.; Jat, M.; Sidhu, H.S. Impacts of laser land leveling in rice-wheat systems of the north-western indo-gangetic plains of India. Food Secur. 2015, 7, 725-738. [CrossRef]

30. Magnan, N.; Spielman, D.J.; Lybbert, T.J.; Gulati, K. Leveling with friends: Social networks and Indian farmers' demand for a technology with heterogeneous benefits. J. Dev. Econ. 2015, 116, 223-251. [CrossRef]

31. Akram, M.W.; Akram, N.; Hongshu, W.; Andleeb, S.; ur Rehman, K.; Kashif, U.; Mehmood, A. Impact of land use rights on the investment and efficiency of organic farming. Sustainability 2019, 11, 7148. [CrossRef]

32. Mottaleb, K.A.; Krupnik, T.J.; Erenstein, O. Factors associated with small-scale agricultural machinery adoption in Bangladesh: Census findings. J. Rural Stud. 2016, 46, 155-168. [CrossRef]

33. Mottaleb, K.A.; Mohanty, S.; Nelson, A. Factors influencing hybrid rice adoption: A Bangladesh case. Aust. J. Agric. Resour. Econ. 2015, 59, 258-274. [CrossRef]

34. Quayum, M.A.; Ali, A.M. Adoption and diffusion of power tillers in Bangladesh. Bangladesh J. Agric. Res. 2012, 37, 307-325. [CrossRef]

35. Kaleem, A.; Abdul Wajid, R. Application of Islamic banking instrument (Bai Salam) for agriculture financing in Pakistan. Br. Food J. 2009, 111, 275-292. [CrossRef]

36. MOP. Long Term Plan for China-Pakistan Economic Corridor (2017-2030); Ministry of Planning, D.R.P., Ed.; China-Pakistpan Economic Corridor: Islamabad, Pakistan, 2017.

37. Jurriëns, M.; Mollinga, P.P.; Wester, P. Scarcity by Design: Protective Irrigation in India and Pakistan; ILRI: Nairobi, Kenya, 1996.

38. Qureshi, A.S.; McCornick, P.G.; Sarwar, A.; Sharma, B.R. Challenges and prospects of sustainable groundwater management in the Indus Basin, Pakistan. Water Resour. Manag. 2010, 24, 1551-1569. [CrossRef]

39. Ullah, A.; Shah, S.N.M.; Ali, A.; Naz, R.; Mahar, A.; Kalhoro, S.A. Factors affecting the adoption of organic farming in Peshawar-Pakistan. Agric. Sci. 2015, 6, 587. [CrossRef]

40. Mariano, M.J.; Villano, R.; Fleming, E. Factors influencing farmers' adoption of modern rice technologies and good management practices in the Philippines. Agric. Syst. 2012, 110, 41-53. [CrossRef]

41. Akram, N.; Akram, M.W.; Hongshu, W. Study on the Socioeconomic Factors Affecting Adoption of Agricultural Machinery. J. Econ. Sustain. Dev. 2020, 11. [CrossRef]

42. Mottaleb, K.A.; Mohanty, S.; Nelson, A. Strengthening market linkages of farm households in developing countries. Appl. Econ. Perspect. Policy 2014, 37, 226-242. [CrossRef]

43. Qureshi, A.S.; Akhtar, M.; Sarwar, A. Effect of electricity pricing policies on groundwater management in Pakistan. Pak. J. Water Resour. 2003, 7, 1-9.

Publisher's Note: MDPI stays neutral with regard to jurisdictional claims in published maps and institutional affiliations. 